Article

\title{
Vectors of Dutch Elm Disease in Northern Europe
}

\author{
Liina Jürisoo ${ }^{1, *}$, Ilmar Süda ${ }^{2}$, Ahto Agan ${ }^{1}$ (I) and Rein Drenkhan ${ }^{1}$ \\ 1 Institute of Forestry and Rural Engineering, Estonian University of Life Sciences, Fr.R. Kreutzwaldi 5, \\ 51006 Tartu, Estonia; ahtoagan@hotmail.com (A.A.); rein.drenkhan@emu.ee (R.D.) \\ 2 Ilmar Süda FIE, Rõõmu tee 12-5, 50705 Tartu, Estonia; ilmar.suda@eesti.ee \\ * Correspondence: liina.jyrisoo@emu.ee
}

check for

updates

Citation: Jürisoo, L.; Süda, I.; Agan, A.; Drenkhan, R. Vectors of Dutch Elm Disease in Northern Europe. Insects 2021, 12, 393. https://doi.org/ $10.3390 /$ insects 12050393

Academic Editor: Domenico Bosco

Received: 10 April 2021

Accepted: 26 April 2021

Published: 29 April 2021

Publisher's Note: MDPI stays neutral with regard to jurisdictional claims in published maps and institutional affiliations.

Copyright: (C) 2021 by the authors. Licensee MDPI, Basel, Switzerland. This article is an open access article distributed under the terms and conditions of the Creative Commons Attribution (CC BY) license (https:// creativecommons.org/licenses/by/ $4.0 /)$.
Simple Summary: Dutch elm disease (DED) has been killing elms for more than a century in northern Europe; the trees' health status has worsened substantially in recent decades. Elm bark beetles Scolytus spp. are vectors of DED. Our aim was to estimate the distribution range of elm bark beetles and to detect potential new vectors of DED agents in northern Europe. Beetles were caught with bottle traps and manually. Then DNA from each specimen was extracted and analysed by the third generation sequencing method. DED agents were detected on the following bark beetles for Europe: Scolytus scolytus, S. triarmatus, S. multistriatus, S. laevis, and on new vectors: Xyleborus dispar and Xyleborinus saxesenii. The spread of Scolytus triarmatus, S. multistriatus and Xyleborinus saxesenii has been remarkable for the last two decades, and S. triarmatus and X. saxesenii are relatively recent newcomers in the northern Baltics. The problem is that the more vectoring beetles there are, the faster spread of Dutch elm disease from tree to tree.

Abstract: Potential Dutch elm disease vector beetle species were caught with pheromone bottle traps and handpicked in 2019: in total, seven species and 261 specimens were collected. The most common was Scolytus triarmatus, but by percent, the incidence of Ophiostoma novo-ulmi was highest in Scolytus scolytus, followed by Xyleborinus saxesenii and S. triarmatus. We analysed the beetles' DNA using PacBio sequencing to determine vector beetles of Ophiostoma novo-ulmi. Ophiostoma novo-ulmi was found on six out of seven analysed beetle species: Scolytus scolytus, S. triarmatus, S. multistriatus, S. laevis, Xyleborinus saxesenii and Xyleborus dispar. The last two beetles were detected as vectors for Ophiostoma novo-ulmi for the first time. Previous knowledge on the spread of beetles is discussed.

Keywords: Scolytus spp.; DED; Xyleborinus saxesenii; Xyleborus dispar; pheromone trap; Ophiostoma novo-ulmi; climate change; PacBio sequencing

\section{Introduction}

There are three native Ulmus species (U. glabra Huds., U. laevis Pall. and U. minor Mill.) in northern Europe. Ulmus glabra, having more northern range, has spread throughout Estonia; $U$. laevis, having more southern range is growing mainly along riversides; $U$. minor native range reaching at its northernmost extent the Baltic Sea and not to northern Baltics [1,2]. Ulmus expanded to Estonia during the Pre-Boreal period, spread rather rapidly, and elms started to decline at the end of the Atlantic period [3].

Elms (Ulmus spp.) as a keystone native forest or amenity species have been under attack globally for more than a century due to the Dutch elm disease causal agent O. ulmi s.l. [4-8]. Dutch elm disease is a lethal vascular wilt disease, the first symptoms of which are yellowing and browning leaves, a cross-section of an elm twig showing brown spots or streaks in the recent wood rings $[9,10]$.

The first pandemic caused by O. ulmi killed $10-40 \%$ of elms by 1960 [8,11,12]; the second more severe pandemic killed some $80-90 \%$ of mature elms by the beginning of the $21 \mathrm{st}$ century in the UK [13,14], as well as hundreds of millions in North America [15]. All native elm species (U. glabra, U. laevis, U. minor) in Sweden endured enormous decimation due to 
DED and were registered on the Red List since 2010 as no long-term viable species [16]. DED has been devastating to various Ulmus species in Estonia, other Baltic countries and in western Russia since the last decade of the 20th century [17-21]. Ophiostomatoid fungal communities (incl. DED) depend on host trees and vector beetles. Coexistence of fungi and their vectors has been studied $[22,23]$ on conifers $[24,25]$ and considerably less on hardwood species [26].

The mycobiota of xylomycetophagous bark beetles is well studied on ambrosia beetles [27]; less studied in Europe, in particular, are phloem-breeding bark and woodboring beetle-associated fungi; those studies were mainly based on morphological criteria [26]. Bark beetles (Coleoptera: Curculionidae, Scolytinae) are distributed worldwide and form many cosmopolitan genera [28]. Although there are many species of scolytids associated with angiosperm trees (hardwoods) [29], nearly all of them are secondary bark beetles as they colonise stressed or damaged trees [6]. A great majority of scolytid beetles on hardwoods are minor pests and are of no economic importance; an exception-some bark beetles connected with elms [5,29]. Elm bark beetles known to vector DED agents include Scolytus kirchi Stalitzky, S. laevis Chaupis, S. multistriatus Marsham with its variety triornatus Eichhoff, S. pygmaeus Fabricius, S. schevyrewi Semenov, S. scolytus Fabricius, S. triarmatus Eggers, S. ulmi L. Redtenbacher and Hylurgopinus rufipes Eichhoff [9,30-34]. Only a few of those are significant $[30,35,36]$, the most important being Scolytus multistriatus $[4,32,37], S$. scolytus $[30,38]$ and S. pygmaeus $[4,36]$.

Several other species of bark beetles which carry fungal associates in mycangium [39] feed in phloem tissues (inner bark), though some larvae engrave outer sapwood [40], being phloeophagous, preferring mostly species from Ulmaceae [5,9]. Elm bark beetles carry DED pathogen spores on the surface of their body and in their gut [30,36,41,42] from diseased to healthy trees, feeding on and tunnelling in twig crotches of healthy elms, transferring fungal spores to xylem tissues [43]. Fungi spreads inside a branch causing blockage of the conducting system because of the formation of tyloses that cause leaves to wilt and die [32].

Some beetle species that live in association with fungi, e.g., ambrosia beetles are xylomycetophagy - feeding on mycelia, consuming wood incidentally [40]. These are polyphagous species of beetles that inhabit many deciduous tree species, incl. Ulmaceae; those common to northern Europe are Xyleborus dispar Fabricius, Xyleborinus saxesenii Ratzeburg and Trypodendron signatum Fabricius [44-46]. There is a slight possibility that DED could be spread by enthomophagous species that follow bark beetles in their tunnels, e.g., Salpingus planirostris and S. ruficollis, which are common on deciduous trees in northern Europe. Both had been caught in tunnels of Scolytus scolytus in the late stages of development [47]. Similarly, there is a minor possibility that Paromalus parallelepipedus and Hololepta plana feeding rarely under the bark of elms [48,49] are potential predatory species on Scolytus species. Together with elm bark beetles, there are at least seven species of bark beetles in the northern Baltics that can potentially spread the Dutch elm disease agent.

Climate change has caused relatively warmer winters and springs than summers and falls, increasing mean annual temperatures [50-52]. This has an impact on trees in forest ecosystems and in urban areas [53]. For example, Ulmus glabra has already started to extend the northern range of its distribution [54,55]. At the same time, climate extremes like unusual fluctuation of temperatures, heavy rains [56], and severe storm events [51] put the hosts under stress and make them susceptible to pests and diseases [51,57]. Those extremities have already caused pathological consequences in Estonian forests [58-63]; new diseases or pests may affect elms, and some may become more aggressive [64,65].

Climate also influences the beetles' outbreaks, their aggressiveness, population dynamics and migration [51] that become more frequent [66]. Usually, the number of scolytid species increased from north to south [67], depending on suitable number of tree species [28]. Warmer climate will probably extend the northern range of Scolytus spp. and affect elm trees in the cooler parts of northern Europe [68], as has happened in northwest Russia [52]. As Scolytus scolytus, S. laevis, S. multistriatus are temperature dependent, beetles may be active for a longer period of time than previously, as they start 
to fly when the mean temperature is at or above $16{ }^{\circ} \mathrm{C}[32,33,47]$ and during an extended warmer period due to climate change.

The aim of the paper is to estimate the distribution of elm bark beetles in Estonia and to detect other potential beetle vectors of DED agents in northern Baltics and the north-western part of Russia.

\section{Materials and Methods}

\subsection{Study Sites and Sampling}

The study sites (Figure 1) were chosen among the locations assessed for DED during 2013-2018 [20,21]. All the sampling sites were located in either urban or rural parks; DED had been found in eight park sites and two well-known elm sites were without previous disease conformation. For trapping beetles, species-specific pheromones (semiochemicals) were used [69].

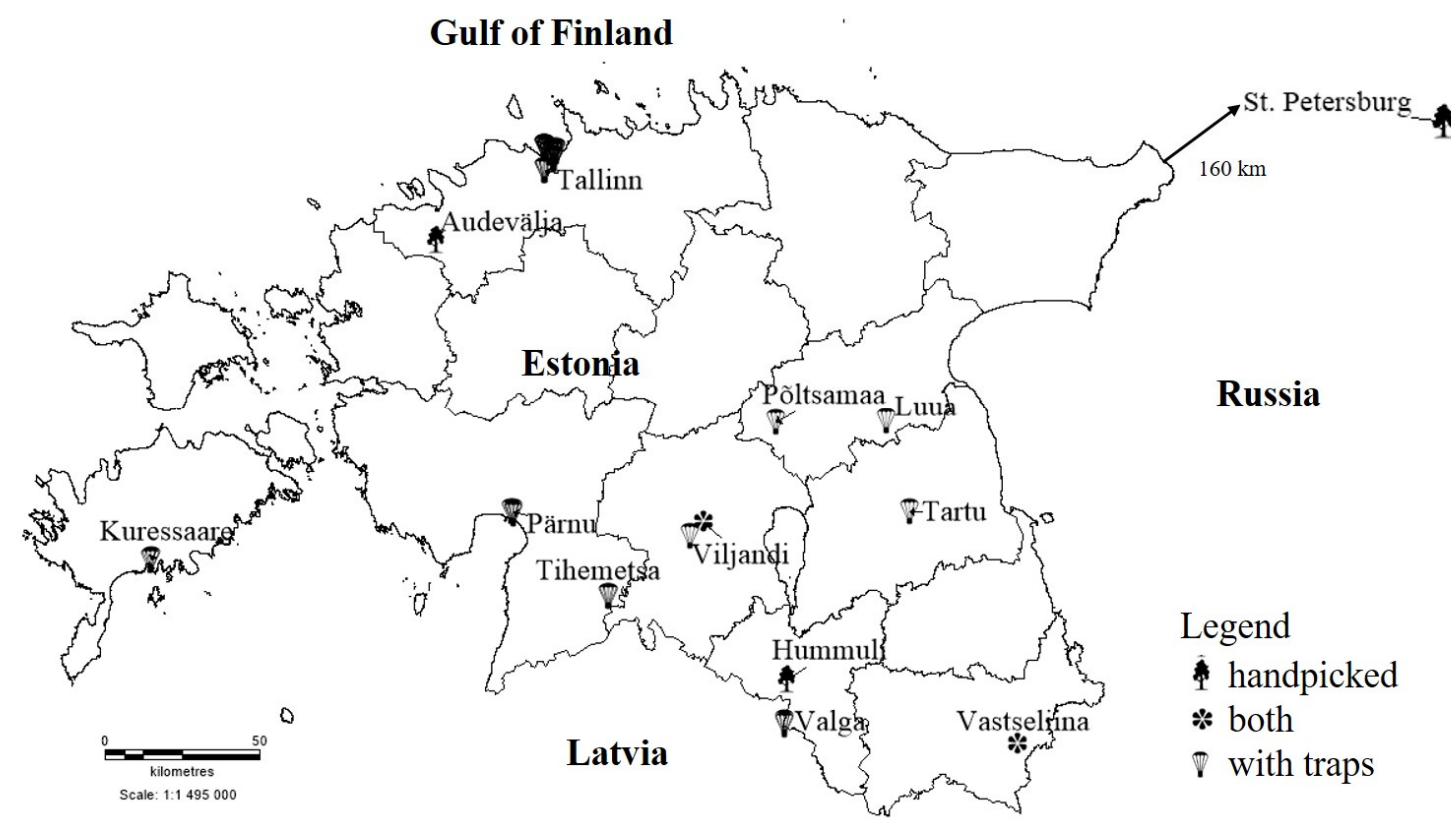

Figure 1. Study sites in Estonia and St. Petersburg, Russia. Bark beetles were handpicked and collected with traps or with both possibilities from the same tree.

Thirty-nine bottle traps (see Figure S1) that contained a 1.5 L plastic bottle with a cut window, plus a smaller bottle with $96 \%$ ethanol on the bottom and a pheromone with attractants for Scolytus spp. were hung on trees in 10 sites at least $50 \mathrm{~m}$ from each other at $3 \mathrm{~m}$ above ground as the most effective height $[70,71]$. Lures consisted of two semipermeable plastic pouches containing a mixture of cubeb oil, 1-hexanol, multistriatin and 4-methyl-3-heptanol (Synergy Semiochemicals Corp., Burnaby, BC, Canada). The lures attract beetles which, while flying towards the lure, hit the plastic sheet, fall into the container with $96 \%$ ethanol and sink. We assume that trapped beetles' cross contamination is eliminated in ethanol. Beetles died in ethanol quickly, traps were checked systematically, and the number of beetles was quite low (generally 1-2 individuals and same species per trap). Twenty-three traps were placed in Tallinn, northern Estonia; 16 traps, throughout Estonia (Figure 1).

Traps were hung in the beginning of June 2019 on what were at the time visually healthy elm trees; sampling was carried out from the second half of June until the beginning of September, at least every three weeks, five times total during the season.

Scolytus-like beetles were immersed in $96 \%$ ethanol for sterilisation and were put in separate tubes and stored in $-20{ }^{\circ} \mathrm{C}$ until further processing. 
To secure a sufficiently large sample size for DNA analysis, we also hand-picked beetles from bark surface of trees at three sites in Estonia (four trees) and one site in St. Petersburg, Russia (three trees). Each specimen was captured into a separate sterile tube.

\subsection{Beetles' Identification}

All beetles caught were identified using an Olympus stereo zoom microscope SZ60 (Olympus Corporation, Japan) with $100 \times$ maximum magnification, based on the following identification keys [72-76]. If necessary, genitals were separated, and the sex of the bark beetles were determined. There were 319 determined beetles in total.

\subsection{Molecular Analyses}

DNA was extracted separately from each beetle's whole body [77] using GeneJET Genomic DNA purification kit (Thermo Fischer Scientific, Vilnius, Lithuania). All 259 collected and determined possible vector beetles were DNA extracted from which 109 were randomly selected, covering different beetle species, sex, locations, and sampling for future analyses.

Primers ITS4ngsUni [78] and ITS1catta [79] were used to amplify fungal DNA and the PCR products were sequenced using PacBio sequencing in the University of Oslo in Norway. Both reverse and forward primers were equipped with 109 different MID tags with 10-12 base length (different pair per sample) that had at least 4 base differences from one another. PacBio has recently been successfully used in metabarcoding analysis of microorganisms on various trees and plants, as the long DNA barcodes of 500-1500 bp can improve OTU identification on a species level [80-82].

Conventional PCR was carried out according to [82] with two replicates for each sample in $25 \mu \mathrm{L}$ reaction volume containing $0.5 \mu \mathrm{L}$ of forward and reverse primer and $5 \mu \mathrm{L}$ of HOT FIRE Pol Blend Master Mix Ready to Load (Solis BioDyne, Tartu, Estonia). Amplification was performed as follows: $15 \mathrm{~min}$ at $95^{\circ} \mathrm{C}$, followed by 25 cycles of $30 \mathrm{~s}$ at $95{ }^{\circ} \mathrm{C} ; 30 \mathrm{~s}$ at $55^{\circ} \mathrm{C} ; 1 \mathrm{~min}$ at $72{ }^{\circ} \mathrm{C}$, and a final step at $72{ }^{\circ} \mathrm{C}$ for $10 \mathrm{~min}$. Positive and negative controls were used throughout the analysis to exclude possible tag switches and sample contamination during the PCR process.

The PCR reactions were checked for the presence of a product on 1\% agarose gel. In the case of no visible band, we repeated the amplification by increasing the number of cycles up to 35. The PCR products were purified using FavorPrep ${ }^{\text {TM }}$ GEL/PCR Purification Kit (Favorgen, Vienna, Austria) following the manufacturer's instructions.

The amplicons were pooled into one sequencing library. Library preparation followed the protocols established for the RSII instrument of PacBio third-generation sequencing platform (Pacific Biosciences, Inc. Menlo Park, CA, USA). The diffusion method was used in loading the library to SMRT cells. Sequencing was performed using P6-C4 chemistry for $10 \mathrm{~h}$ following Tedersoo et al. [83].

\subsection{Bioinformatics and Statistical Analysis}

Bioinformatics was carried out by using various programs implemented in Pipecraft v1.0 [84].

Using mothur (v1.36.1) [85], reads < 100 bp were removed and longer sequences were demultiplexed allowing 2-base differences to index and 3-base differences to primer. UCHIME [86] was used in de novo chimera filtering. The full-length Internal Transcribed Spacer (ITS) region was extracted from the rRNA genes with program ITSx (v1.0.11) [87]. CD-HIT (v4.6) [87] was used to cluster sequences into Operational Taxonomic Units (OTUs) based on $97 \%$ sequence similarity. OTUs were taxonomically identified based on representative sequences against the UNITE v.7 database [88]. OTUs were considered as members of fungi if their representative sequences matched the best fungal taxa at e-value $<\mathrm{e}-50$. Representative sequences that had $>97 \%$ sequence similarity to reference sequences were assigned to species hypotheses (SHs) based on UNITE [89]. Higher level classification of fungi was based on the e-value and sequence similarity criteria of Tedersoo et al. [78]. 
Differences of percentage of $O$. novo-ulmi between sampling methods, sampling areas, beetle species and genders were analysed using ANOVA with Tukey HSD in Excel and were considered significant with $p$ value $\leq 0.05$.

\section{Results}

\subsection{Collected Beetle Species}

In total, 319 specimens of beetles (28 different species) were caught, from which 93 specimens of 23 beetle species were captured with pheromone-baited bottle traps ( 28 of the 39 traps contained beetles). The number of potential vector beetle individuals for DED was 261 , from which $81 \%$ of beetles were handpicked in four sites from seven different trees; $9 \%$ were trapped. The number of potential DED vector beetles collected with traps and symptomatic trees are presented by species, country, and gender in Table 1. The other beetle species collected are listed in Supplementary Materials Table S1.

Table 1. Potential vector beetle species of DED caught with traps and handpicked from symptomatic trees.

\begin{tabular}{|c|c|c|c|c|c|c|}
\hline \multirow{3}{*}{ Species of Beetles } & \multirow{3}{*}{ Country } & \multirow{2}{*}{\multicolumn{2}{|c|}{$\begin{array}{c}\text { Traps } \\
\text { Sex }\end{array}$}} & \multirow{2}{*}{\multicolumn{2}{|c|}{$\begin{array}{c}\text { Handpicked } \\
\text { Sex }\end{array}$}} & \multirow{3}{*}{ Total } \\
\hline & & & & & & \\
\hline & & Male & Female & Male & Female & \\
\hline \multirow{2}{*}{ Scolytus multistriatus } & Estonia & 3 & 3 & - & - & 6 \\
\hline & Russia & - & - & 5 & - & 5 \\
\hline \multirow{2}{*}{$\begin{array}{l}\text { Scolytus triarmatus } \\
\text { Scolytus laevis }\end{array}$} & Estonia & 4 & 2 & 66 & 114 & 186 \\
\hline & Estonia & - & - & 21 & 18 & 39 \\
\hline Scolytus scolytus & Russia & - & - & 2 & 2 & 4 \\
\hline Scolytus pygmaeus & Russia & - & - & - & 1 & 1 \\
\hline \multirow{3}{*}{$\begin{array}{c}\text { Xyleborinus saxesenii } \\
\text { Xyleborus dispar }\end{array}$} & Estonia & - & 10 & - & - & 10 \\
\hline & Estonia & - & 10 & - & - & 10 \\
\hline & Total & \multicolumn{2}{|c|}{32} & \multicolumn{2}{|c|}{229} & 261 \\
\hline
\end{tabular}

\subsection{Ophiostoma novo-ulmi on Vector Beetles}

The number of sequenced individuals was 109; the selection was based on beetle specimens that covered different beetle species, sex, locations and different collecting methods.

The entire sequenced dataset consisted of 33,202 high quality sequences across 109 beetle specimen samples and 655 OTUs (see Genbank accession number PRJNA719602).

Ophiostoma novo-ulmi was found on six out of seven beetle species. Only S. pygmaeus had no O. novo-ulmi. Among the most caught species was S. triarmatus; the pathogen was detected in $77 \%$ of analysed specimens.

In total, 2757 O. novo-ulmi ITS sequences were found in the dataset, constituting $8.3 \%$ of all sequences within the dataset (see https://dx.doi.org/10.15156/BIO/807454, accessed on 15 April 2021). Ophiostoma novo-ulmi was the most prevalent species in this dataset. The highest average percentage of O. novo-ulmi per sample was found on beetle species S. scolytus, followed by X. saxesenii and S. triarmatus with $26.6 \%, 20.5 \%$ and $18.2 \%$, respectively; although considerable, these differences among species were not statistically significant, possibly due to a large variation in sample sizes among species $\left(\mathrm{F}_{5.101}=1.89\right.$; $p=0.101$; Figure 2). The difference between genders was also not statistically significant $\left(\mathrm{F}_{5.101}=0.001 ; p=0.993\right)$. Comparison between handpicked and trapped specimens resulted no significant difference in percentages of $O$. novo-ulmi $\left(\mathrm{F}_{1 \cdot 80}=0.04 ; p=0.848\right)$. The beetles handpicked directly from trees had $8.7 \%$ of sequences identified as O. novo-ulmi, whereas $8.1 \%$ of $O$. novo-ulmi was found on beetles collected with traps. When comparing the relative abundance of $O$. novo-ulmi across 15 different sampling sites and all beetle species, the highest percentage of O. novo-ulmi was found in site Tallinn (Kopli), North Estonia, followed by site Vastseliina, Southeast Estonia and site St. Petersburg, Russia with $27.7 \%, 18.7 \%$ and $15.4 \%$, respectively. According to ANOVA with Tukey HSD O. novo-ulmi 
percentage differences between sites were not statistically significant $\left(\mathrm{F}_{8.91}=1.42 ; p=0.196\right)$. For more precise distribution data of O. novo-ulmi across the sampling sites, beetle species and gender, see Supplementary Table S2.

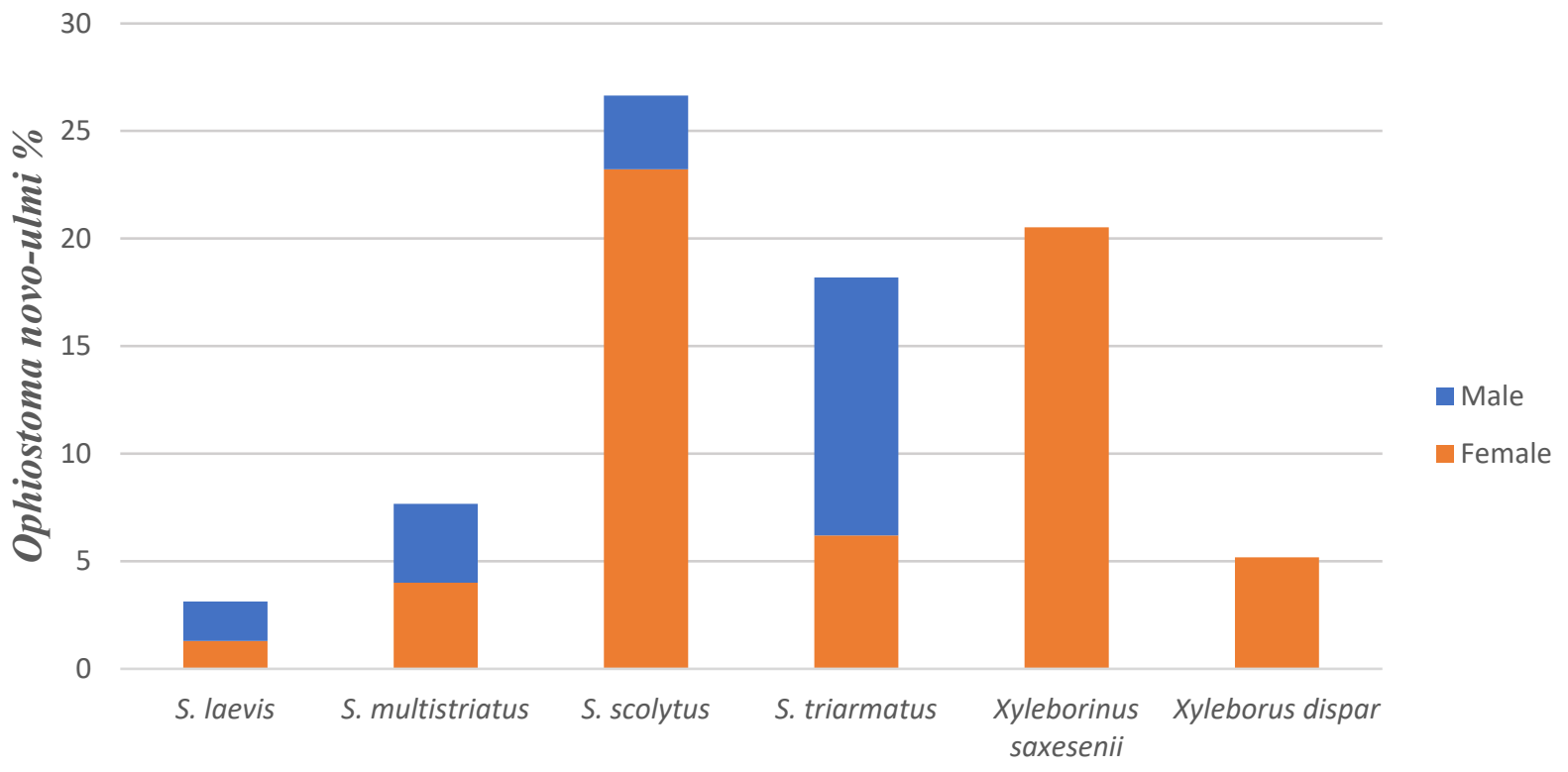

Species

Figure 2. Percentage of $O$. novo-ulmi across different beetle species and gender $(\mathrm{N}=109)$. No O. novo-ulmi was found on $S$. pygmaeus.

\section{Discussion}

\subsection{Beetles as Vectors of O. novo-ulmi and Pathogen Detection}

When referring to beetles that spread Dutch elm disease, in particular, we mean those species that can inhabit living elms, their bark and/or wood.

According to PacBio sequencing, we found the pathogen in six commonly captured beetle species (S. scolytus, S. laevis, S. multisriatus, S. triarmatus, X. saxesenii, X. dispar; see Figure 2). Among those, $X$. saxesenii and $X$. dispar were found as new vectors for Dutch elm disease in northern Europe. Ophiostoma novo-ulmi was not detected on S. pygmaeus in this study.

Bark and ambrosia beetles are an optimal vehicle for the transport of different organisms, incl. fungi, from one host to another [40].

Until now, the main culprits in the spread of Dutch elm disease have been Scolytus spp. [4,32,37]. Knowing the biology of Scolytinae and their suitable host trees, the range of these potential vector species is somewhat wider. In addition to Scolytus sp., host species from family Ulmaceae are inhabited by at least the following species of beetles common in northern Europe: Xyleborus dispar, Xyleborinus saxesenii and Trypodendron signatum [44-46]. These are polyphagous pests that inhabit many deciduous tree species but may rarely occur in conifers as well. Xyleborus dispar can also attack healthy trees, especially when those are close to stressed hosts $[89,90]$.

Most ambrosia beetles do not feed on wood, but Xyleborinus saxesenii is an exception. The larvae feed on the ectosymbiotic fungus growing in wood and the wood itself, classifying this species as xylomycetophagous, rather than just mycetophagous (feeding only on fungi) [91]. Xyleborinus saxesenii is strongly attracted to ethanol-based baits and often accumulates in ethanol-baited traps in numbers greater than other ambrosia beetles [92]. Most cases where the species is reported as aggressive to stressed hosts include elms [93].

In Poland O. novo-ulmi subsp. novo-ulmi was isolated not from only the elm-infecting beetles but also from Hylesinus crenatus on Fraxinus excelsior and Scolytus intricatus on 
Quercus robur [22]. Ophiostoma novo-ulmi was found on an unknown vector and on other host species than elms, thus the pathogen occurrence in forest ecosystems is much broader than previously thought $[22,94]$.

The pathogen detection from biological samples incl. vector beetles is highly crucial to estimate the disease spread and occurrence. Thus, we note that primers ITS1catta and ITS4ngsUni and PacBio sequencing platform worked well identifying O. novo-ulmi from different bark beetle species. The primers were able to distinguish O. novo-ulmi across 33,202 ITS sequences and 655 OTU-s. Ophiostoma novo-ulmi was the most prevalent species in this dataset: $8.3 \%$ of sequences were identified as $O$. novo-ulmi with the average length of $O$. novo-ulmi amplicons being $612 \mathrm{bp}$. We sequenced the ITS region, which does not differentiate $O$. novo-ulmi subspecies, but we have evidence that the subspecies may have different aggressiveness (see $[17,95])$. Thus, species-specific DNA primers are needed to differentiate $O$. novo-ulmi subspecies from biological samples for faster detection of the spread of pathogen.

\subsection{Spread of Vectors for DED in Estonia and Northwest Russia}

Scolytus bark beetles are the main vectors for the transmission of DED, introducing the pathogen into visually healthy trees during adult feeding and breeding.

Scolytus multistriatus was found to vector O. novo-ulmi in the current work and the pathogen was detected in about $8 \%$ of analysed individuals. The northernmost European finding of Scolytus multistriatus was recorded in a park in St. Petersburg in 1997 [96,97], and later in Vyborg (B.G. Popovichev, pers. comm.). It was first registered in Estonia, close to Tartu in about 1900 [98], then was rediscovered in southern Estonia: Taheva (1967) and Karisöödi (1996) [99]. Since 2012, the species has been relatively abundant on the Koiva wooded meadow near Vaitka, South Estonia. According to the latest data, in 2019, S. multistriatus has already reached central Estonia.

Scolytus laevis, of which $2.5 \%$ of the analysed individuals contained the pathogen, is the most widely spread species of its genera in Estonia and Russia [100] but has been found much farther north in Sweden and Norway than in the central parts of the Leningrad Region $[96,97]$. It was recorded for the first time in South Estonia at Heimtali, Viljandi County in 1936 [101], a few years later, in 1938, also from Viljandi, central Estonia [102]. Scolytus laevis was also found in northern Estonia [103] and is now widespread presumably throughout the Estonian mainland. Years ago, DED was rarely spread by this species [100] but it has been currently proved as a vector of DED in our region.

Scolytus scolytus, of which more than fourth of analysed specimens contained O. novoulmi. The northernmost recordings of S. scolytus in Europe were found in St. Petersburg's city parks in $2000[97,104]$ and later in Vyborg (B.G. Popovichev, pers. comm.). It should be mentioned that in Sweden, S. scolytus has been completely replaced by the related species S. triarmatus, which was reported from even farther northern Sweden, compared with $S$. scolytus in Estonia [104]. Only two dead specimens were found in Estonia on the island of Abruka in western Estonia (leg. et det. I. Süda): 1 qunder the bark of on old dead elm in 1994 and $10^{7}$ under the bark of a thick branch of an old elm in $1997[99,105,106]$.

Scolytus triarmatus, of which $18 \%$ of analysed specimens carried O. novo-ulmi. The first finding of $S$. triarmatus in Estonia (also in the Baltics) originated from Soontaga, southern Estonia in 2004 [106]. It is noteworthy that in 2012, in the park of Linnamäe manor in south-eastern Estonia, the entire trunk of one of Estonia's thickest elms $(\mathrm{CBH}=5 \mathrm{~m})$ was quite massively inhabited by this species (observation by I. Süda). S. triarmatus has now strongly expanded its distribution in Estonia. In 2019, it was caught from Tartu, Vastseliina, Viljandi, Hummuli in southern Estonia and several sites in Tallinn, northern Estonia. In addition, all the above-mentioned vectors of DED occur in the northern European part of Russia as well, except $S$. triarmatus [75].

Scolytus pygmaeus has not been detected in Estonia as of yet, but recently appeared in northwest Russia in 2012 [97,100,107], being native in the central Russian territories [108]. It is likely to have spread along the roadside of the highway from Moscow to St. Peters- 
burg [97], where planted elm stands served as corridors for leading northwards [109]; the same is true of S. multistriatus and S. scolytus. One single individual was collected from Russia, but O. novo-ulmi was not detected. Scolytus pygmaeus was found to be the vector of pathogen [110].

Ophiostomatoid fungi associate with phloem-breeding and ambrosia beetles on hardwoods [22] but there are some notes indicating higher species diversity as vectors than that previously reported from Europe [22].

Xyleborinus saxesenii-20\% of analysed specimens contained the pathogen. The first record of X. saxesenii was in western Estonia from the Laulaste Nature Reserve, southeastern Estonia in 2008 and from Matsalu, western Estonia in 2009 [111]. Later, X. saxesenii was found from two localities in South Estonia, Valga County: Koiva wooded meadow in 2013 and Soontaga in 2015, 2020. This work confirmed the beetle's first finding in 2019 and it was caught with traps from several localities in Tallinn, northern Estonia. Xyleborinus saxesenii is capable of breeding in various hosts [24,93] including elms [112]. Like other ambrosia beetles, $X$. saxesenii breeds mostly in weakened or dying trees. Xyleborinus saxesenii has been considered an insignificant pest until recently, when it has been proved to spread O. novo-ulmi. Additionally, X. saxesenii has been shown to be able to spread the laurel wilt pathogen Raffaelea lauricola (Ophiostomatales) [14,112,113].

Xyleborus dispar and Trypodendron signatum are known to occur on a wide range of deciduous trees $[113,114]$. Both species are native, common and widespread throughout Estonia, but the latter was not found on elms. However, Xyleborus dispar was proved to be the vector of $O$. novo-ulmi in this work, e.g., $5 \%$ of analysed specimens contained $O$. novo-ulmi.

The implementation of such highly efficient research methods as the use of window traps has helped to detect new woodland beetle species for Estonian fauna [111,115]. On the other hand, as a result of climate change, the spread of numerous southern beetle species to the north is clearly noticeable [115], especially in the last couple of decades. The same is true for the DED vectors Scolytus multistriatus and Xyleborinus saxesenii. However, it is not clear why Scolytus triarmatus has become widespread and numerous in Estonia in such a short time. Considering that Scolytus triarmatus does not occur in Latvia, Lithuania nor Finland, the ambiguity is even greater.

\subsection{The Traps and Alcohol as a Baiting Compound}

Bark beetles are strongly attracted to synthetic pheromone $[71,116]$ thus pheromone traps can be used to indicate their presence.

Traps used in our research were made from $1.5 \mathrm{~L}$ plastic bottles, because these are cost effective [92]. The number of species and specimens caught with pheromone-baited bottle traps used in this study indicate quite low efficiency as used in current work. If the pheromone was created to attract specifically for Scolytus spp., then ethanol is known to affect many saproxylic beetles, including bark beetles [45,117]. A comparative study in France proved that the overall specimen collecting efficiency of alcohol-baited traps in catching saproxylic beetles was twice as large as that of nonbaited traps, the efficiency ratio amounting even to 114 in catching Xyleborinus saxesenii! [117]. It can be assumed that in Estonia too, a relatively large number of Xyleborinus saxesenii and Xyleborus dispar specimens were lured into pheromone traps due to the attractiveness of ethanol; this does not directly indicate the high abundance of both species in the study sites. It is probable that ethanol has also an attracting effect on Scolytus spp. species. During the sampling, there were usually 1-2 specimens per trap at a time, so cross-contamination was diminished between same species individuals and different species. Thus, low efficiency of trapping fit well with the current work tasks.

Possible vectors could be also predators of Scolytinae: Salpingus planirostris and Paromalus parallelepipedus [118]. Salpingus planirostris is a common species mainly found on deciduous trees including Ulmus, and P. parallelepipedus inhabits mainly conifers, occasion- 
ally some deciduous trees as well, including Ulmus [49]. Therefore, it is not a coincidence that some specimens were caught on elms in Estonia.

\section{Conclusions}

This study provides new information on vectors for Dutch elm disease in northern Europe. From all 319 beetle specimens caught either with traps or handpicked-261 specimens were potential vectors of Dutch elm disease. High throughput sequencing indicated that Ophiostoma novo-ulmi was the most represented fungus $(8.2 \%)$ on six out of seven analysed beetle species. The highest percentage of O. novo-ulmi was found on beetle species $S$. scolytus, followed by X. saxesenii and S. triarmatus.

According to the latest studies of potential DED vectors, the rather rapid expansion of the distribution of three species-Scolytus triarmatus, S. multistriatus and Xyleborinus saxesenii-in Estonia is remarkable. The first two have expanded northwards, currently spreading to the centre line of Estonia, S. triarmatus in addition to north-western Estonia. It is noteworthy that $S$. triarmatus and $X$. saxesenii are relatively recent newcomers in Estonia, first registered in 2004 and 2008, respectively. Whereas previously the most common Scolytus-species on elms in Estonia was S. laevis, now it seems to be S. triarmatus.

In conclusion, the results of our work with known elm bark beetles (Scolytus laevis, S. multistriatus, S. triarmatus and S. scolytus), indicates that there are two more species that can potentially spread Dutch elm disease in Estonia: Xyleborus dispar and Xyleborinus saxesenii. We did not catch one potential DED vector Trypodendron signatum on Ulmus, thus a connection with O. novo-ulmi cannot be confirmed in Estonia.

Since this was a monitoring study, there is not enough data on the extent of infection in the areas-differences between sampling sites, beetle species and sexes. A study of these named aspects could be the focus of future work.

The spread of DED should be controlled with ongoing survey of trees and the monitoring of vectoring beetles with the help of pheromone traps. Removing of all diseased elms as soon as possible is a key factor to protect healthy elms. Additionally, new and reliable species-specific DNA primers are needed for quick pathogen detection from biological samples to control disease spread.

Supplementary Materials: The following are available online at https://dx.doi.org/10.15156/BIO/ 807454, Figure S1: In current work used bottle trap with pheromone; Table S1: Other insect species caught with traps and handpicked; Table S2: Relative abundance of O. novo-ulmi across different sampling sites and beetle species.

Author Contributions: The original idea and study design were developed by L.J., R.D. and I.S. Data and samples collection was provided by L.J. and I.S. Laboratory work, data analysis, and interpretation of results were provided by L.J., A.A. and I.S. The first draft of the manuscript was written by L.J. and A.A. The statistical analyses were chosen and overseen by A.A. All authors have read and agreed to the published version of the manuscript.

Funding: This study was supported by the Estonian Science Foundation grant PSG136, the Estonian Environmental Investments Centre, Tallinn City Government, and the European Union, European Regional Development Fund Estonian University of Life Sciences ASTRA Project "Value-chain based bio-economy".

Institutional Review Board Statement: Not applicable.

Data Availability Statement: Full ITS sequences of the entire dataset are uploaded into SRA under accession number PRJNA719602. Filtered representative full ITS sequences of O. novo-ulmi are uploaded into PlutoF: https:/ / dx.doi.org/10.15156/BIO/807454, accessed on 15 April 2021.

Acknowledgments: We would like to thank Kaljo Voolma for valuable suggestions and comments to the manuscript and Marguerite Oetjen (native speaker from USA) for the English revision. We thank four anonymous reviewers for valuable comments and suggestions for manuscript.

Conflicts of Interest: The authors declare no conflict of interest. 


\section{References}

1. Kukk, T.; Kull, T. Eesti Taimede Levikuatlas (Atlas of the Estonian Flora); Eesti Maaülikooli Põllumajandus- ja Keskkonnainstituut; Institute of Agricultural and Environmental Sciences of the Estonian University of Life Sciences: Tartu, Estonia, 2005; 528p. (In Estonian)

2. Caudullo, G.; De Rigo, D. Ulmus_elms in Europe: Distribution, habitat, usage and threats. In European Atlas of Forest Tree Species; San-Miguel-Ayanz, J., de Rigo, D., Caudullo, G., Durrant, H.T., Mauri, A., Eds.; Publications Office of the EU: Luxembourg, 2016; p. e01bd40.

3. Saarse, L.; Veski, S. Spread of broad-leaved trees in Estonia. Proc. Est. Acad. Sci. Geol. 2001, 50, 51. Available online: https:/ / www.researchgate.net/publication/252516467_Spread_of_broad-leaved_trees_in_Estonia (accessed on 6 April 2021).

4. Santini, A.; Faccoli, M. Dutch elm disease and elm bark beetles: A century of association. iForest Biogeosci. For. 2015, 8, 126-134. [CrossRef]

5. Smith, S.M.; Hulcr, J. Scolytus and other Economically Important Bark and Ambrosia Beetles. Bark Beetles 2015, 495-531. [CrossRef]

6. Wingfield, M.J.; Garnas, J.R.; Hajek, A.; Hurley, B.P.; De Beer, Z.W.; Taerum, S.J. Novel and co-evolved associations between insects and microorganisms as drivers of forest pestilence. Biol. Invasions 2016, 18, 1045-1056. [CrossRef]

7. Martín, J.A.; Sobrino-Plata, J.; Rodríguez-Calcerrada, J.; Collada, C.; Gil, L. Breeding and scientific advances in the fight against Dutch elm disease: Will they allow the use of elms in forest restoration? New For. 2019, 50, 183-215. [CrossRef]

8. Brasier, C.M. Intercontinental Spread and Continuing Evolution of the Dutch Elm Disease Pathogens. In The Elms; Springer Science and Business Media LLC: Berlin/Heidelberg, Germany, 2000; pp. 61-72.

9. Clinton, G.P.; McCormick, F.A. Dutch Elm Disease. Graphium Ulmi; Connecticut Agricultural Experimental Station, Bulletin 386: New Haven, CT, USA, 1936; pp. 701-752.

10. Stipes, R.J.; Campana, R.J. Compendium of Elm Diseases; Stipes, R.J., Campana, R.J., Eds.; American Phytopathological Society: Saint Paul, MN, USA, 1981.

11. Peace, T.R. The status and development of Elm Disease in Britain. Comm Bull. 1960, 33, 44.

12. Gibbs, J.N. Intercontinental Epidemiology of Dutch Elm Disease. Annu. Rev. Phytopathol. 1978, 16, 287-307. [CrossRef]

13. Brasier, C.; Buck, K. Rapid Evolutionary Changes in a Globally Invading Fungal Pathogen (Dutch Elm Disease). Biol. Invasions 2001, 3, 223-233. [CrossRef]

14. Kirisits, T. Dutch elm disease and other Ophiostoma diseases. Infect. For. Dis. 2013, 2013, 256-282. [CrossRef]

15. Brasier, C.M. Rapid Evolution of Introduced Plant Pathogens via Interspecific Hybridization is leading to rapid evolution of Dutch elm disease and other fungal plant pathogens. Bioscience 2001, 51, 123-133. [CrossRef]

16. Gärdenfors, U. The 2010 Red List of Swedish Species. Available online: https:/ / www.artdatabanken.se/globalassets/ew/subw / artd/2.-var-verksamhet/publikationer/4.-rodlista-2010/274614_inlaga_liten_sid-del1-1-199.pdf (accessed on 27 November 2019).

17. Jürisoo, L.; Selikhovkin, A.V.; Padari, A.; Shevchenko, S.V.; Shcherbakova, L.N.; Popovichev, B.G.; Drenkhan, R. The extensive damages of elms by Dutch elm disease agents and their hybrids in north-western Russia. Urban For. Urban Green. 2021. submitted.

18. Matisone, I.; Kenigsvalde, K.; Zaluma, A.; Burneviča, N.; Šnepste, I.; Matisons, R.; Gaitnieks, T. First report on the Dutch elm disease pathogen Ophiostoma novo-ulmi from Latvia. For. Pathol. 2020, e12601. [CrossRef]

19. Motiejūnaitè, J.; Kutorga, E.; Kasparavičius, J.; Lygis, V.; Norkutė, G.; Jurga, M.; Ernestas, K.; Jonas, K.; Vaidotas, L.; Goda, N. New records from Lithuania of fungi alien to Europe. Mycotaxon 2016, 131, 49-60. [CrossRef]

20. Jürisoo, L.; Padari, A.; Drenkhan, R. Jalakasurma levikust ja ohtlikkusest Eestis (Spread and riskiness of Dutch elm disease in Estonia). For. Stud. Metsanduslikud Uurim. 2021, submitted. (In Estonian)

21. Jürisoo, L.; Adamson, K.; Padari, A.; Drenkhan, R. Health of elms and Dutch elm disease in Estonia. Eur. J. Plant Pathol. 2019, 154, 823-841. [CrossRef]

22. Jankowiak, R.; Strzałka, B.; Bilański, P.; Kacprzyk, M.; Wieczorek, P.; Linnakoski, R. Ophiostomatoid fungi associated with hardwood-infesting bark and ambrosia beetles in Poland: Taxonomic diversity and vector specificity. Fungal Ecol. 2019, 39, 152-167. [CrossRef]

23. Pajares, J.A.; García, S.; Díez, J.J.; Martín, D.; García-Vallejo, M.C. Feeding Responses by Scolytus scolytus to Twig Bark Extracts from Elms. Investig. Agraria Sist. Recur. For. 2004, 13, 217-225.

24. Kirisits, T. Fungal Associates of European Bark Beetles with Special Emphasis on the Ophiostomatoid Fungi. In Bark and Wood Boring Insects in Living Trees in Europe, a Synthesis; Metzler, J.B., Ed.; Springer: Berlin, Germany, 2007; Volume 2007, pp. 181-236.

25. Linnakoski, R. Bark beetle-associated fungi in Fennoscandia with special emphasis on species of Ophiostoma and Grosmannia. Diss. For. 2011, 2011. [CrossRef]

26. Aas, T.; Solheim, H.; Jankowiak, R.; Bilański, P.; Hausner, G. Four new Ophiostoma species associated with hardwood-infesting bark beetles in Norway and Poland. Fungal Biol. 2018, 122, 1142-1158. [CrossRef]

27. Mayers, C.G.; McNew, D.L.; Harrington, T.C.; Roeper, R.A.; Fraedrich, S.W.; Biedermann, P.H.; Castrillo, L.A.; Reed, S.E. Three genera in the Ceratocystidaceae are the respective symbionts of three independent lineages of ambrosia beetles with large, complex mycangia. Fungal Biol. 2015, 119, 1075-1092. [CrossRef]

28. Heliövaara, K.; Peltonen, M. Bark Beetles in a Changing Environment. Ecol. Bull. 1999, 48-53. [CrossRef]

29. Ohmart, C.P. Why are There so Few Tree-Killing Bark Beetles Associated with Angiosperms? Oikos 1989, 54, 242. [CrossRef] 
30. Webber, J.F. Relative effectiveness of Scolytus scolytus, S. multistriatus and S. kirschi as vectors of Dutch elm disease. For. Pathol. 1990, 20, 184-192. [CrossRef]

31. Sherif, S.; Jones, A.; Shukla, M.; Saxena, P. Establishment of invasive and non-invasive reporter systems to investigate American elm-Ophiostoma novo-ulmi interactions. Fungal Genet. Biol. 2014, 71, 32-41. [CrossRef]

32. Menkis, A.; Östbrant, I.-L.; Davydenko, K.; Bakys, R.; Balalaikins, M.; Vasaitis, R. Scolytus multistriatus associated with Dutch elm disease on the island of Gotland: Phenology and communities of vectored fungi. Mycol. Prog. 2016, 15, 1-8. [CrossRef]

33. Anderbrant, O.; Schlyter, F. Ecology of the Dutch Elm Disease Vectors Scolytus laevis and S. scolytus (Coleoptera: Scolytidae) in Southern Sweden. J. Appl. Ecol. 1987, 24, 539. [CrossRef]

34. Anderbrant, O.; Yuvaraj, J.K.; Martin, J.A.; Rodriguez-Gil, J.L.; Witzell, J. Feeding by Scolytus bark beetles to test for differently susceptible elm varieties. J. Appl. Entomol. 2017, 141, 417-420. [CrossRef]

35. Tarigan, M.; Roux, J.; Van Wyk, M.; Tjahjono, B.; Wingfield, M. A new wilt and die-back disease of Acacia mangium associated with Ceratocystis manginecans and C. acaciivora sp. nov. in Indonesia. South. Afr. J. Bot. 2011, 77, 292-304. [CrossRef]

36. Webber, J.F. Experimental studies on factors influencing the transmission of Dutch elm disease. Investig. Agrar. Sist. Recur. 2004, $13,197$.

37. Lindelöw, Å. Introduced or Overlooked? New Bark Beetle Species in Sweden (Coleoptera; Curculionidae). Forstsch. Aktuell. 2012, 55, 28. Available online: https://bfw.ac.at/400/pdf/fsaktuell_55_10.pdf (accessed on 24 May 2019).

38. Waller, M. Drought, disease, defoliation and death: Forest pathogens as agents of past vegetation change. J. Quat. Sci. 2013, 28, 336-342. [CrossRef]

39. Hulcr, J.; Stelinski, L.L. The Ambrosia Symbiosis: From Evolutionary Ecology to Practical Management. Annu. Rev. Entomol. 2017, 62, 285-303. [CrossRef] [PubMed]

40. Kirkendall, L.R.; Biedermann, P.H.; Jordal, B.H. Evolution and Diversity of Bark and Ambrosia Beetles. Bark Beetles 2015, 2015, 85-156. [CrossRef]

41. Bernier, L.; Aoun, M.; Bouvet, G.; Comeau, A.; Dufour, J.; Naruzawa, E.; Nigg, M.; Plourde, K. Genomics of the Dutch elm disease pathosystem: Are we there yet? iForest Biogeosci. For. 2015, 8, 149-157. [CrossRef]

42. Moser, J.C.; Konrad, H.; Blomquist, S.R.; Kirisits, T. Do mites phoretic on elm bark beetles contribute to the transmission of Dutch elm disease? Naturwissenschaften 2009, 97, 219-227. [CrossRef] [PubMed]

43. Sherif, S.M.; Erland, L.A.; Shukla, M.R.; Saxena, P.K. Bark and wood tissues of American elm exhibit distinct responses to Dutch elm disease. Sci. Rep. 2017, 7, 1-11. [CrossRef]

44. Koch, K. Die Kaefer Mitteleuropas, 3rd ed.; Goecke \& Evers: Krefeld, Germany, 1992; 370p.

45. Nikulina, T.; Mandelshtam, M.; Petrov, A.; Nazarenko, V.; Yunakov, N. A survey of the weevils of Ukraine. Bark and ambrosia beetles (Coleoptera: Curculionidae: Platypodinae and Scolytinae). Zootaxa 2015, 3912, 1-61. [CrossRef]

46. Yanovskiy, V.M. Annotirovannyy spisok koroyedov (Scolytidae) Severnoy Azii (Annotated list of bark beetles (Scolytidae) of North Asia). Entomol. Rev. 1999, 78, 327-362. (In Russian)

47. Beaver, R.A. Notes on the fauna associated with elm bark beetles in Wytham Wood, Berks-I Coleoptera. Entomol. Mon. Mag. 1966, 102, 163-170.

48. Borowski, J.; Mazur, S. Beetles (Coleoptera) of the Rogów Region-Part IV—Clown Beetles (Histeridae) and False Clown Beetles (Sphaeritidae). Int. Lett. Nat. Sci. 2015, 37, 10-17. [CrossRef]

49. Troukens, W. Paromalus parallelepipedus (Coleoptera: Histeridae) aan de westrand van Brussel (Paromalus parallelepipedus (Coleoptera: Histeridae) at the westside of Brussels). Phegea 2015, 43. Available online: www.faunaeur.org (accessed on 21 January 2021). (In Dutch).

50. Vose, R.S.; Easterling, D.R.; Gleason, B. Maximum and minimum temperature trends for the globe: An update through Geophys. Res. Lett. 2005, 32, 1-5. [CrossRef]

51. Bentz, B.J.; Jönsson, A.M. Modeling Bark Beetle Responses to Climate Change. Bark Beetles 2015, 2015, 533-553. [CrossRef]

52. Selikhovkin, A.V.; Drenkhan, R.; Mandelshtam, M.Y.; Musolin, D.L. Invasions of insect pests and fungal pathogens of woody plants into the northwestern part of European Russia. Vestnik St. Petersburg Univ. Earth Sci. 2020, 65, 263-283. [CrossRef]

53. Sturrock, R.N.; Frankel, S.J.; Brown, A.V.; Hennon, P.E.; Kliejunas, J.T.; Lewis, K.J.; Worrall, J.J.; Woods, A.J. Climate change and forest diseases. Plant Pathol. 2011, 60, 133-149. [CrossRef]

54. Kullman, L. Changes in alpine plant cover-effects of climate warming. Sven. Bot. Tidskr. 2003, 97, 210.

55. Drobyshev, I.V. Effect of natural disturbances on the abundance of Norway spruce (Picea abies (L.) Karst.) regeneration in nemoral forests of the southern boreal zone. For. Ecol. Manag. 2001, 140, 151-161. [CrossRef]

56. Roloff, A.; Korn, S.; Gillner, S. The Climate-Species-Matrix to select tree species for urban habitats considering climate change. Urban For. Urban Green. 2009, 8, 295-308. [CrossRef]

57. Hanso, M.; Drenkhan, R. Metsa-ja linnapuud ilmastiku äärmuste vaevas (Trees in forests and towns are suffering from the extreme weather conditions). Eesti Lood Est. Nat. 2007, 58, 6-13. (In Estonian)

58. Hanso, M.; Drenkhan, R. Simple visualization of climate change for improving the public perception in forest pathology/Kliimamuutuste visualiseerimise lihtne viis seoste paremaks tajumiseks metsapatoloogias. For. Stud. 2013, $58,37-45$. [CrossRef]

59. Adamson, K.; Drenkhan, R.; Hanso, M. Invasive brown spot needle blight caused by Lecanosticta acicola in Estonia. Scand. J. For. Res. 2015, 30, 587-593. [CrossRef] 
60. Drenkhan, R.; Riit, T.; Adamson, K.; Hanso, M. The earliest samples of Hymenoscyphus albidus vs. H. fraxineus in Estonian mycological herbaria. Mycol. Prog. 2016, 15, 835-844. [CrossRef]

61. Hanso, M.; Drenkhan, R. Diplodia pinea is a new pathogen on Austrian pine (Pinus nigra) in Estonia. Plant Pathol. 2009, 58, 797. [CrossRef]

62. Hanso, M.; Drenkhan, R. Lophodermium needle cast, insect defoliation and growth responses of young Scots pines in Estonia. For. Pathol. 2011, 42, 124-135. [CrossRef]

63. Lutter, R.; Drenkhan, R.; Tullus, A.; Jürimaa, K.; Tullus, T.; Tullus, H. First record of Entoleuca mammata in hybrid aspen plantations in hemiboreal Estonia and stand-environmental factors affecting its prevalence. Eur. J. For. Res. 2019, 138, 263-274. [CrossRef]

64. Braschler, B.; Hill, J.K. Role of larval host plants in the climate-driven range expansion of the butterfly Polygonia c-album. J. Anim. Ecol. 2007, 76, 415-423. [CrossRef]

65. Hemery, G.E.; Clark, J.R.; Aldinger, E.; Claessens, H.; Malvolti, M.E.; O’Connor, E.; Raftoyannis, Y.; Savill, P.S.; Brus, R. Growing scattered broadleaved tree species in Europe in a changing climate: A review of risks and opportunities. Forestry 2009, 83, 65-81. [CrossRef]

66. Cudmore, T.J.; Björklund, N.; Carroll, A.L.; Lindgren, B.S. Climate change and range expansion of an aggressive bark beetle: Evidence of higher beetle reproduction in naïve host tree populations. J. Appl. Ecol. 2010, 47, 1036-1043. [CrossRef]

67. Lekander, B.; Bejer-Petersen, B.; Kangas, E.; Bakke, A. The distribution of bark beetles in the Nordic countries. Acta. Entomol. Fenn. 1977, 32. Available online: https://www.cabdirect.org/cabdirect/abstract/19770548371 (accessed on 15 January 2021).

68. Caulton, E.; Aitken, W.; Rashid, N. Aerobiological aspects of elm (Ulmus spp.) in South-East Scotland in relation to elm decline from Dutch Elm disease (1976-1996). Aerobiologia 1998, 14, 147-153. [CrossRef]

69. Brand, J.M.; Young, J.C.; Silverstein, R.M. Insect Pheromones: A Critical Review of Recent Advances in Their Chemistry, Biology, and Application. In Fortschritte der Chemie Organischer Naturstoffe Progress in the Chemistry of Organic Natural Products; Springer Science and Business Media LLC: Berlin/Heidelberg, Germany, 1979; Volume 37, pp. 1-190.

70. Cuthbert, R.A.; Peacock, J.W. Attraction of Scolytus multistriatus to Pheromone-baited Traps at Different Heights. Environ. Entomol. 1975, 4, 889-890. [CrossRef]

71. Neumann, F.G.; Minko, G. Studies on the introduced smaller European elm bark beetle, Scolytus multistriatus, a potential vector of Dutch elm disease in Victoria. Aust. For. 1985, 48, 116-126. [CrossRef]

72. Schedl, K.E. Familie: Scolytidae (Borken- und Ambrosiakäfer). In Die Käfer Mitteleuropas; Freude, H., Harde, K.W., Lohse, G.A., Eds.; Goecke \& Evers: Krefeld, Germany, 1981; pp. 34-99.

73. Pfeffer, A. Familie: Scolytidae. In Die Käfer Mitteleuropas, Supplementband Mit Katalogteil; Lohse, G.A., Lucht, W.H., Eds.; Goecke \& Evers: Krefeld, Germany, 1994; pp. 153-180.

74. Pfeffer, A. Zentral- und Westpaläarktische Borken- und Kernkäfer (Coleoptera: Scolytidae, Platypodidae); Pro Entomologia, c/o Naturhistorisches Museum: Basel, Switzerland, 1995; 370p.

75. Petrov, A.V.; Mandelshtam, M.Y.; Beaver, R.A. A key to species of the tribe Scolytini Latreille, 1804 (Coleoptera: Curculionidae: Scolytinae) from Russia and adjacent countries. REJ 2019, 28, 286-302. [CrossRef]

76. Voolma, K.; Õunap, H.; Süda, I. Eesti Ürasklaste (Coleoptera, Scolytidae) Määraja (A Key of Estonian Bark Beetles (Coleoptera, Scolytidae)); Eesti Loodusfoto: Tartu, Estonia, 1997; 43p. (In Estonian)

77. Drenkhan, T.; Voolma, K.; Adamson, K.; Sibul, I.; Drenkhan, R. The large pine weevil Hylobius abietis (L.) as a potential vector of the pathogenic fungus Diplodia sapinea (Fr.) Fuckel. Agric. For. Entomol. 2017, 19, 4-9. [CrossRef]

78. Tedersoo, L.; Bahram, M.; Põlme, S.; Kõljalg, U.; Yorou, N.S.; Wijesundera, R.L.C.; Ruiz, L.V.; Vasco-Palacios, A.M.; Thu, P.Q.; Suija, A.; et al. Global diversity and geography of soil fungi. Science 2014, 346, 1256688. [CrossRef]

79. Tedersoo, L.; Anslan, S. Towards PacBio-based pan-eukaryote metabarcoding using full-length ITS sequences. Environ. Microbiol. Rep. 2019, 11, 659-668. [CrossRef]

80. Loit, K.; Adamson, K.; Bahram, M.; Puusepp, R.; Anslan, S.; Kiiker, R.; Drenkhan, R.; Tedersoo, L. Relative performance of Oxford Nanopore MinION vs. Pacific Biosciences Sequel third-generation sequencing platforms in identification of agricultural and forest pathogens. Appl. Environ. Microbiol. 2019, 85, e01368-19. [CrossRef]

81. Tedersoo, L.; Drenkhan, R.; Anslan, S.; Morales-Rodriguez, C.; Cleary, M. High-throughput identification and diagnostics of pathogens and pests: Overview and practical recommendations. Mol. Ecol. Resour. 2018, 19, 47-76. [CrossRef]

82. Agan, A.; Drenkhan, R.; Adamson, K.; Tedersoo, L.; Solheim, H.; Børja, I.; Matsiakh, I.; Timmermann, V.; Nagy, N.E.; Hietala, A.M. The Relationship between Fungal Diversity and Invasibility of a Foliar Niche-The Case of Ash Dieback. J. Fungi 2020, 6, 150. [CrossRef]

83. Tedersoo, L.; Tooming-Klunderud, A.; Anslan, S. PacBio metabarcoding of Fungi and other eukaryotes: Errors, biases and perspectives. New Phytol. 2018, 217, 1370-1385. [CrossRef]

84. Anslan, S.; Bahram, M.; Hiiesalu, I.; Tedersoo, L. PipeCraft: Flexible open-source toolkit for bioinformatics analysis of custom high-throughput amplicon sequencing data. Mol. Ecol. Resour. 2017, 17, e234-e240. [CrossRef]

85. Schloss, P.D.; Westcott, S.L.; Ryabin, T.; Hall, J.R.; Hartmann, M.; Hollister, E.B.; Lesniewski, R.A.; Oakley, B.B.; Parks, D.H.; Robinson, C.J.; et al. Introducing mothur: Open-Source, Platform-Independent, Community-Supported Software for Describing and Comparing Microbial Communities. Appl. Environ. Microbiol. 2009, 75, 7537-7541. [CrossRef] [PubMed]

86. Edgar, R.C.; Haas, B.J.; Clemente, J.C.; Quince, C.; Knight, R. UCHIME Improves Sensitivity and Speed of Chimera Detection. Bioinformatics 2011, 27, 2194-2200. [CrossRef] [PubMed] 
87. Bengtsson-Palme, J.; Ryberg, M.; Hartmann, M.; Branco, S.; Wang, Z.; Godhe, A.; De Wit, P.J.G.M.; Sánchez-García, M.; Ebersberger, I.; De Sousa, F.; et al. Improved software detection and extraction of ITS1 and ITS2 from ribosomal ITS sequences of fungi and other eukaryotes for analysis of environmental sequencing data. Methods Ecol. Evol. 2013, 4, 914-919. [CrossRef]

88. Kõljalg, U.; Nilsson, R.H.; Abarenkov, K.; Tedersoo, L.; Taylor, A.F.S.; Bahram, M.; Bates, S.T.; Bruns, T.D.; Bengtsson-Palme, J.; Callaghan, T.M.; et al. Towards a unified paradigm for sequence-based identification of fungi. Mol. Ecol. 2013, 22, 5271-5277. [CrossRef] [PubMed]

89. Kühnholz, S.; Borden, J.H.; Uzunovic, A. Secondary Ambrosia Beetles in Apparently Healthy Trees: Adaptations, Potential Causes and Suggested Research. Integr. Pest Manag. Rev. 2001, 6, 209-219. [CrossRef]

90. Speranza, S.; Bucini, D.; Paparatti, B. New observation on biology of european shot-hole borer [xyleborus dispar (f.)] on hazel in northern latium (central italy). Acta Hortic. 2009, 845, 539-542. [CrossRef]

91. Deyrup, M.; Atkinson, T. Comparative Biology of Temperate and Subtropical Bark and Ambrosia Beetles (Coleoptera: Scoly-tidae, Platypodidae) in Indiana and Florida. Gt Lakes Entomol. 1987, 20, 59.

92. Steininger, M.S.; Hulcr, J.; Igut, M.; Lucky, A.; Sigut, M. Simple and Efficient Trap for Bark and Ambrosia Beetles (Coleoptera: Curculionidae) to Facilitate Invasive Species Monitoring and Citizen Involvement. J. Econ. Entomol. 2015, 108, 1115-1123. [CrossRef]

93. Rabaglia, R.J.; Dole, S.A.; Cognato, A.I. Review of American Xyleborina (Coleoptera: Curculionidae: Scolytinae) Occurring North of Mexico, with an Illustrated Key. Ann. Entomol. Soc. Am. 2006, 99, 1034-1056. [CrossRef]

94. Chang, R.; Duong, T.A.; Taerum, S.J.; Wingfield, M.J.; Zhou, X.; De Beer, Z.W. Ophiostomatoid fungi associated with coniferinfesting beetles and their phoretic mites in Yunnan, China. MycoKeys 2017, 28, 19-64. [CrossRef] [PubMed]

95. Brasier, C.M.; Kirk, S.A. Designation of the EAN and NAN races of Ophiostoma novo-ulmi as subspecies. Mycol. Res. 2001, 105, 547-554. [CrossRef]

96. Mandelshtam, M.Y.; Popovichev, B.G. Annotated list of bark beetle species (Coleoptera, Scoytidae) of the Leningrad Region. Entomol. Rev. 2000, 80, 887-903.

97. Mandelshtam, M.Y.; Selikhovkin, A.V. Bark and Ambrosia Beetles (Coleoptera, Curculionidae: Scolytinae) of Northwest Russia: History of the Study, Composition and Genesis of the Fauna. Entomol. Rev. 2020, 100, 1-27. [CrossRef]

98. Zolk, K. Kodumaa ürasklased (Ipidae) ühes lühikese ülevaatega nende bionoomiast ja levimisest Eestis (Native bark beetles (Ipidae) together with a brief overview of their bionomy and distribution in Estonia). Eesti Metsanduse Aastaraam. Est. Yearb. 1932, 6, 127-176. (In Estonian)

99. Voolma, K.; Süda, I. Rare species of Cerambycidae and Scolytidae (Coleoptera) in Estonia. In Proceedings of the XXIV Nordic Congress of Entomology, Tartu, Estonia, 8-11 August 1997; pp. 187-192.

100. Shcherbakova, L.N.; Mandelshtam, M.Y. Vyazy Sankt Peterburga: Posle tret'yego zvonka (Elms of Saint Petersburg: After the third ring). In Proceedings of the International Conference the Kataev Memorial Readings-VIII, St. Peterburg, Russia, 18-20 November 2014; Musolin, D.L., Selikhovkin, A.V., Eds.; Saint Petersburg State Forest Technical University: Saint Petersburg, Russia, 2014. (In Russian).

101. Kristian, J. Mõnest uuest üraskiliigist Eestis (About some new beetle species in Estonia). Eesti Mets Estonian For. 1937, 17, 399. (In Estonian)

102. Leius, K. Täiendavaid andmeid ürasklaste (Ipidae) esinemise kohta Eestis (Additional data on the occurrence of bark beetles (Ipidae) in Estonia). Eesti Metsanduse Aastaraam. Est. Yearb. 1939, 9, 318-328. (In Estonian)

103. Voolma, K.; Õunap, H.; Süda, I. Eesti Putukate Levikuatlas, 2: Ürasklased-Scolytidae (Distribution Maps of Estonian Insects, 2: Scolytidae); Eesti Loodusfoto: Tartu, Estonia, 2000; 84p. (In Estonian)

104. Voolma, K.; Mandelshtam, M.; Shcherbakov, A.; Yakovlev, E.; Õunap, H.; Süda, I.; Popovichev, B.; Sharapa, T.; Galasjeva, T.; Khairetdinov, R.; et al. Distribution and spread of bark beetles (Coleoptera: Scolytidae) around the Gulf of Finland: A comparative study with notes on rare species of Estonia, Finland and North-Western Russia. Entomol. Fenn. 2004, 15, 198-210. [CrossRef]

105. Voolma, K.; Süda, I.; Õunap, H. New records of bark beetles (Coleoptera, Scolytidae) from Estonia. Proc. Est. Acad. Sci. Biol. Ecol. 1998, 47, 73-78.

106. Süda, I. Jalaka-maltsaürask (Scolytus triarmatus (Eggers, 1912))—uus üraskiliik Baltikumis Scolytus triarmatus (Eggers, 1912)—new bark beetle in the Baltics. Metsanduslikud Uurim. 2006, 44, 112-117. (In Estonian)

107. Mandelshtam, M.Y.; Khayretdinov, R.R. Additions to the list of species of bark beetles (Coleoptera, Curculionidae: Scolytinae) of the Leningrad Region (Dopolneniya k spisku vidov koroyedov (Coleoptera, Curculionidae: Scolytinae) Leningradskoy oblasti. Entomol. Rev. 2017, 86, 512-521. (In Russian)

108. Petrov, A.V.; Nikitsky, N.B. Scolytid fauna (Coleoptera, Scolytidae) of Moscow Province. Entomol. Obozr. 2001, 80, 353.

109. Vlasov, D.V.; Mandelshtam, M.Y. Elm bark beetles of the genus Scolytus Geoffroy, 1762 (Coleoptera: Scolytidae) as new serious pests in the parks of Yaroslavl and Saint Petersburg. In Proceedings of the Fitosanitarnoe Ozdorovlenie Ekosistem. Materialy Vtorogo Vserossiiskogo s"Ezda Po Zashchite Rastenii: V 2 Tomakh (Phytosanitary Improvement of Ecosystems: Proceedings of the 2nd All-Russian Plant Protection Congress in Two Volumes, St. Petersburg, FL, USA, 9-11 September 2005; Volume 1, p. 262. (In Russian).

110. Ganley, R.J.; Bulman, L.S. Dutch elm disease in New Zealand: Impacts from eradication and management programmes. Plant Pathol. 2016, 65, 1047-1055. [CrossRef] 
111. Süda, I. Metsamardikate (Coleoptera) uued liigid Eestis (New woodland beetle species (Coleoptera) in Estonian fauna). For. Stud. 2009, 50, 98-114. (In Estonian) [CrossRef]

112. Biedermann, P.H. Observations on sex ratio and behavior of males in Xyleborinus saxesenii Ratzeburg (Scolytinae, Coleoptera). ZooKeys 2010, 56, 253-267. [CrossRef]

113. Salmane, I.; Ciematnieks, R.; Ozolina-Pole, L.; Ralle, B.; Ievinsh, G. Investigation of European shot-hole borer, Xyleborus dispar (Coleoptera, Scolytidae), in apple orchards of Latvia. In Proceedings of the International Scientific and Practical Conference, Rezekne, Latvia, 18-20 June 2015; Volume 2, pp. 256-260.

114. Süda, I. Metsamardikate (Coleoptera) uued liigid Eestis. 2 (New woodland beetle species (Coleoptera) in Estonian fauna. 2). For. Stud. 2016, 64, 51-69. (In Estonian) [CrossRef]

115. Süda, I. Mardikauurimisest viimastel aastakümnetel (1990-2009) (Coleoptera studies in recent decades (1990-2009)). In Year-Book of the Estonian Naturalists' Society, 86th ed.; Kull, T., Liira, J., Sammul, M., Eds.; Eesti Looduseuurijate Seltsi Aastaraamat; Eesti Looduseuurijate Selts: Tartu, Estonia, 2011; pp. 225-229. (In Estonian)

116. Helland, I.S.; Hoff, J.M.; Anderbrant, O. Attraction of bark beetles (Coleoptera: Scolytidae) to a pheromone trap. J. Chem. Ecol. 1984, 10, 723-752. [CrossRef]

117. Bouget, C.; Brustel, H.; Brin, A.; Valladares, L. Evaluation of window flight traps for effectiveness at monitoring dead woodassociated beetles: The effect of ethanol lure under contrasting environmental conditions. Agric. For. Entomol. 2009, 11, 143-152. [CrossRef]

118. Wegensteiner, R.; Wermelinger, B.; Herrmann, M. Natural Enemies of Bark Beetles: Predators, Parasitoids, Pathogens, and Nematodes. In Bark Beetles; Academic Press: Cambridge, MA, USA, 2015; pp. 247-304. [CrossRef] 